\title{
Correction to: The Changing Shelf Life of Chilled, Vacuum-Packed Red Meat
}

John Sumner, Paul Vanderlinde, Mandeep Kaur, and Ian Jenson

\section{Correction to:}

Chapter 8 in: P. J. Taormina, M. D. Hardin (eds.),

Food Safety and Quality-Based Shelf Life of Perishable Foods, Food Microbiology and Food Safety, https://doi.org/10.1007/978-3-030-54375-4_8

The original version of this chapter was inadvertently published with incorrect name of the first author as John Summer, and the same has been corrected as John Sumner. 